\title{
Intentie en uitvoeringspraktijk van decentrale selectie van studenten geneeskunde - een analyse over de criteria
}

\author{
Th.J. ten Cate, P.J. Klijnhout
}

\section{Samenvatting}

Probleem: De wetgever heeft met de introductie van decentrale selectie in het hoger onderwijs in 1999 criteria voor ogen die vooral, maar niet uitsluitend, gericht zijn op voorgaande prestaties. Sindsdien zijn door diverse medische faculteiten criteria en procedures ontwikkeld, waarvan sommigen menen dat zij de intentie van de wet niet goed weerspiegelen. Er is daarom behoefte aan een analyse van de bedoelingen rond de criteria.

Methode: De criteria die de faculteiten voor 2002/2003 hebben geformuleerd zijn geïnventariseerd. Daarnaast zijn uit documenten aanwijzingen voor de te stellen criteria achterhaald: in het bijzonder uit de toelichting bij het wetsvoorstel, de wetstekst, en de latere correspondentie van de minister en de Begeleidingscommissie Decentrale Toelating. De analyse was gericht op discrepanties in deze stukken.

Resultaat: Negentien discussiepunten zijn geformuleerd. In nogal wat aanwijzingen voor de te stellen criteria zijn tegenstrijdigheden te vinden. Faculteiten die sinds 1999 selectiecriteria hebben geformuleerd zijn er nog niet in geslaagd de intentie van de wetgever en het facultaire belang met elkaar te verenigen.

Discussie: Het is zeer de vraag of de intentie van de wet, om vooral het gedrag van de scholier te beïvloeden ('lot in eigen hand') door toepassing van niet-cognitieve criteria, goed combineerbaar zal zijn met criteria die vooral predictief valide zijn, hetgeen primair het facultaire belang is. (Cate ThJ ten, Klijnhout PJ. Intentie en uitvoeringspraktijk van decentrale selectie van studenten geneeskunde - een analyse van de criteria. Tijdschrift voor Medisch Onderwijs 2002;21(3): 91-103.)

\section{Inleiding}

Selectie voor de studie geneeskunde is sinds de wijziging van de Wet op het hoger onderwijs en wetenschappelijk onderzoek van 3 april 1999 mogelijk op basis van criteria die door de faculteiten worden bepaald. ${ }^{1}$

$\mathrm{Nu}$ sinds enkele jaren door meerdere faculteiten geselecteerd wordt, is het zinvol na te gaan in hoeverre faculteiten erin zijn geslaagd selectiecriteria te kiezen die acceptabel zijn voor alle relevante partijen. Als relevante partijen kunnen worden beschouwd (a) de wetgever, in casu de wetstekst en de toelichting hierbij, (b) de door de minister van Onderwijs, Cultuur en Wetenschappen (OCenW) ingestelde Begeleidingscommissie Decentrale Toelating, in casu haar rapportage en brieven, (c) de minister zelf in een brief en (d) de faculteiten geneeskunde.

Het rapport Gewogen Loting Gewogen onderscheidt zes hoofdmodaliteiten in selectiebeslissingen, te weten selectie op basis van (a) het lot, (b) verwacht studiesucces, (c) prestaties in het voortraject, (d) prestaties tijdens de studie en (e) zelfselectie. ${ }^{2}$ Voor de analyse in dit artikel zijn a, d en e niet relevant, omdat zij buiten de opdracht van decentrale selectie vallen. Wel relevant zijn: (b) verwacht studiesucces (en wellicht zelfs verwacht beroepssucces) en (c) prestaties in het voortraject. Daarnaast zijn criteria denk- 
baar die niet direct aan meetbare prestaties zijn gerelateerd, zoals motivatie. Deze driedeling stemt overeen met de indeling die Drenth presenteert voor selectie van de beste kandidaten voor een vast aantal plaatsen: "verdienste", "geschiktheid" en "motivatie". 3

\section{Methode}

\section{Gehanteerde criteria in 2002}

In tabel 1 is een samenvatting gegeven van de criteria die voor de toelating tot het studiejaar 2002/2003 zullen worden gehanteerd. Deze zijn ontleend aan brieven die in mei 2001 naar het Disciplineoverleg Medische Wetenschappen zijn gezonden en websites van de geneeskundefaculteiten van de Universiteit van Amsterdam (UvA, AMC), de Vrije Universiteit Amsterdam (VUA, VUmc), de Universiteit Leiden (UL, LUMC), Universiteit Utrecht (UU, UMCU) en de Erasmus Universiteit Rotterdam (EUR) ${ }^{4}$ Uit de procedurebeschrijvingen kan worden opgemaakt dat er mogelijk veel meer overlap is in criteria dan uit de formeel gestelde criteria blijkt.

De indicatoren die met een worden aangeduid, beperken zich tot de uitdrukkelijk geformuleerde criteria in correspondentie of op websites. Impliciete criteria zijn met $\bigcirc$ aangegeven. Er is afgezien van een onderscheid tussen primaire criteria, waaraan de kandidaat in ieder geval moet voldoen om tot nadere selectie te worden toegelaten en de nadere criteria zelf. Zo wordt in Utrecht een afgeronde opleiding als absolute voorwaarde gesteld, terwijl dit in Amsterdam (zowel UvA als VUA) een van de alternatieve primaire criteria is, naast andere alternatieven. Er is een categorisering van zes rubrieken aangebracht. Opleiding, activiteiten/ervaringen tijdens of na school en voorgaande prestaties zijn te beschouwen als "verdienste", vaardigheden voor studie of beroep en toekomstvisie als "geschiktheid" en belangstellingen als "motivatie", indien men de indeling van Drenth volgt. Overigens kunnen criteria soms in meerdere rubrieken worden ondergebracht.

\section{Aanwijzingen omtrent criteria, gegeven} door de wet, de minister en de Begeleidingscommissie Decentrale Toelating

In het regeerakkoord van 1998 wordt voor het eerst een kader gegeven voor de keuze van selectiecriteria: “(...) er zullen experimenten komen met alternatieve vormen van toelating tot studies met een numerus fixus (in plaats van loting). Het gaat om systemen van selectie waarbij eindexamen, inzet, motivatie en specifieke talenten gewogen zullen worden." 5 Als bronnen voor de aanwijzingen zijn gehanteerd de toelichting bij het wetsvoorstel van 1997/98, de tekst van de wet van 3 april 1999, de correspondentie en verslaglegging van de Begeleidingscommissie Decentrale Toelating (Commissie Sorgdrager) uit 1999 en 2001, en een brief van de minister van OCenW van 12 april 2001. Zij worden in chronologische volgorde besproken. Uitsluitend aanwijzingen of opmerkingen die betrekking hebben op de selectiecriteria zijn uit de stukken gelicht. Telkens is met cursieve passages aangegeven aan welke teksten uit deze documenten de conclusies zijn ontleend.

\section{Toelichting bij het wetsvoorstel (1998) ${ }^{6}$}

- Vooral voorafgaande prestaties zijn van belang.

"Een kernpunt is dat aankomende studenten hun eigen toelatingskansen moeten kunnen beïnvloeden, c.q. beter beloond worden voor de inspanning die zij zich gedurende hun vooropleiding getroosten om zich gericht te kwalificeren voor fixusopleidingen. Voorafgaande prestaties moeten bij de selectieprocedure voor fixus- 
Tabel 1. Criteria en procedures bij de selectie van geneeskundestudenten in 2002.

\begin{tabular}{|c|c|c|c|c|c|}
\hline Criteria voor $2002 / 2003$ & AMC & VUmc & LUMC & UMCU & EUR \\
\hline \multicolumn{6}{|l|}{ Opleiding } \\
\hline Diploma wo en/of hbo (geheel of gedeeltelijk) & $\bullet$ & $\bullet$ & & $\bullet$ & \\
\hline Extra vak(ken) in het examenpakket & • & • & • & & \\
\hline Geen herkansingen van vwo-examens & & & $\bullet$ & & \\
\hline Invulling vrije ruimte vwo & & - & & & 0 \\
\hline (Profiel)werkstuk(en) & & - & & & O \\
\hline \multicolumn{6}{|l|}{ Activiteiten/ervaringen tijdens of na school } \\
\hline Buitenschoolse activiteiten/vrijwilligerswerk & & $\bullet$ & & & O \\
\hline Werkervaring (in de gezondheidszorg) & - & $\bullet$ & & & \\
\hline Bestuurlijke en/of organisatorische ervaring & & $\bullet$ & & & $\bullet$ \\
\hline Ervaring in het buitenland & & $\bullet$ & & & \\
\hline \multicolumn{6}{|l|}{ Voorgaande prestaties } \\
\hline Wetenschappelijke prestaties & & & & & $\bullet$ \\
\hline Sportieve prestaties & & • & & & $\bullet$ \\
\hline Artistieke prestaties & & $\bullet$ & & & $\bullet$ \\
\hline Activiteiten waaruit bijzonder talent blijkt & & $\bullet$ & & & O \\
\hline \multicolumn{6}{|l|}{ Vaardigheden voor studie of beroep } \\
\hline Sociale vaardigheid & $\bullet$ & $\bullet$ & & O & \\
\hline Studievaardigheid, passend bij de opleiding & O & & O & • & \\
\hline Probleemoplossend vermogen & & & • & O & \\
\hline Communicatief vermogen & & & $\bullet$ & 0 & \\
\hline \multicolumn{6}{|l|}{ Toekomstvisie } \\
\hline Realistisch beeld van het beroep & & & & $\bullet$ & \\
\hline Realistisch beeld van de studie & & & & $\bullet$ & \\
\hline Realistisch beeld van de eigen studieplanning & & & & - & \\
\hline Visie op de meerwaarde van eerder gevolgde opleiding & & & & • & \\
\hline \multicolumn{6}{|l|}{ Belangstellingen } \\
\hline Affiniteit met hulpverlening & O & O & & & $\bullet$ \\
\hline Brede oriëntatie & & & & & $\bullet$ \\
\hline Motivatie voor de eigen faculteit & $\bullet$ & $\bullet$ & & & \\
\hline Affiniteit met onderzoek & & $\bullet$ & & & \\
\hline Activiteiten waaruit motivatie blijkt & & $\bullet$ & & O & O \\
\hline Gefundeerde motivatie voor het beroep & & O & & • & \\
\hline Aantoonbare affiniteit met multiculturele samenleving & & $\bullet$ & & & \\
\hline Procedures en instrumenten voor $2002 / 2003$ & AMC & VUmc & LUMC & UMCU & EUR \\
\hline Sollicitatiebrief en/of -formulier & & $\bullet$ & & $\bullet$ & $\bullet$ \\
\hline Interview & & $\bullet$ & & $\bullet$ & \\
\hline Computer/multimedia test sociale vaardigheden & - & & & & \\
\hline Assessment-studietaak & & & & • & \\
\hline Vragenlijst beroepsbeeld & & & & $\bullet$ & \\
\hline Studieactiviteiten & $\bullet$ & & • & & $\bullet$ \\
\hline Essay & - & & - & & \\
\hline Toets over gevolgd onderwijs & • & & - & & \\
\hline
\end{tabular}

- expliciete criteria; $\bigcirc$ impliciete criteria. 
opleidingen nadrukkelijker worden beloond dan volgens de bestaande systematiek."

- Faculteiten mogen zelf de criteria stellen, gericht op eindexamencijfers, inzet, motivatie en specifieke talenten.

"Ik acht het noodzakelijk dat de instellingen met name tijdens de experimentele fase over de nodige vrijheid beschikken. Dit geldt in elk geval voor de toelatingscriteria. Zij krijgen de ruimte om ervaring op te doen op het gebied van decentrale selectie, via experimenten waaraan zij op basis van eindexamencijfers, inzet, motivatie en specifieke talenten naar eigen inzicht vorm geven en - tastenderwijs - criteria te ontwikkelen"

- Voorselectie is mogelijk, bijvoorbeeld op basis van vrije ruimte in de profielkeuze. "Ook kan de instelling een voorselectie toepassen, bij voorbeeld door van de gegadigden te verlangen dat steeds sprake is van een specifieke, inhoudelijk doelgerichte invulling van de vrije ruimte binnen de profielkeuze in het voortgezet onderwijs of van specifieke keuzes in het voorafgaande beroepsonderwijs."

- 'Hardheid' door uitloting kan in criteria meegenomen worden.

"Ik zou niet willen uitsluiten dat instellingen bij de decentrale selectie mede betrekken het toelaten van gegadigden waarvoor uitloting een onbillijkheid van overwegende aard zou opleveren."

- Procedures moeten helder, transparant en vlot zijn.

- Criteria moeten een relatie hebben met de aansluitende beroepsuitoefening.

- Criteria mogen niet discriminatoir zijn.

"De gegadigden die zich aanmelden voor decentrale selectie mogen van de instellingen die decentrale selectie toepassen, verwachten dat deze heldere criteria stellen, een transparante procedure toepassen, toelatingsverzoeken vlot behandelen en beginselen van behoorlijk bestuur hanteren. Aanvechtbaar lijken mij in dat verband criteria die geen relatie hebben met de desbetreffende opleiding of met de daarop aansluitende beroepsuitoefening. Ook een selectiecriterium dat neerkomt op discriminatie, zal door de rechter niet worden aanvaard. Wel lijken mij criteria die rekening houden met goede schoolprestaties in vakken die specifiek relevant zijn voor de opleiding, al dan niet in samenhang met andere criteria, zinvol. Decentrale selectie moet betrekking hebben op het identificeren van een bijzondere geschiktheid, gelet op de inrichting van het onderwijs en gelet op het beroepenveld en de ontwikkelingen daarbinnen."

- Er zijn geen geschikte instrumenten om op voorhand ongemotiveerdheid vast te stellen.

"De Stichting Lotgenoten pleit voor een drempel ter beperking van deelname van ongemotiveerde studenten aan de selectie geneeskunde. Het aanleggen van een drempel vereist dat vooraf op ondubbelzinnige wijze kan worden vastgesteld wie al dan niet voldoende gemotiveerd is. Daarvoor zijn evenwel geen geschikte instrumenten voorhanden."

\section{Wet op het hoger onderwijs en weten- schappelijk onderzoek (wet van 3 april 1999) 1}

- De instelling selecteert kandidaten naar eigen oordeel op 'bijzondere kwalificaties'.

- Aan deze kwalificaties kunnen nadere selectiecriteria toegevoegd worden.

- Behaalde eindexamencijfers zijn als criterium niet toegestaan.

- Men moet aan de algemene toelatingseisen voor de opleiding voldoen. 
- Men moet tevens meedoen aan de loting (maximaal driemaal).

- De faculteit bepaalt of men een-, twee of driemaal aan de selectieprocedure mag meedoen.

- Meedoen aan decentrale selectie kan niet als men al elders voor eenzelfde opleiding is/was ingeschreven.

"Artikel 7.57e. Selectie door instellingen

1. Een instellingsbestuur kan een door hem te bepalen percentage van de opleidingsplaatsen van een opleiding toewijzen aan door hem zelf geselecteerde gegadigden die naar zijn oordeel beschikken over bijzondere kwalificaties. Dat percentage is aan een maximum gebonden, doordat:

a. in elk geval ten minste de helft van het aantal opleidingsplaatsen dient te worden toegewezen door toepassing van artikel $7.57 c$, tweede lid,

b.op dat percentage tevens in mindering wordt gebracht het aantal gegadigden dat een bewijs van toelating ontvangt door toepassing van artikel $7.57 c$, eerste lid.

2. Indien het instellingsbestuur toepassing geeft aan het eerste lid, maakt het

a. de bijzondere kwalificaties die het in aanmerking wil nemen,

b. eventuele nadere selectiecriteria,

c. regels van administratieve aard, voorzover niet voortvloeiend uit het vierde lid,

d.het door hem te bepalen percentage, bedoeld in het eerste lid, en

e. de beslissing of gegadigden één, twee dan wel drie maal tot deelname aan de selectieprocedure zullen worden toegelaten, tijdig bekend.

3. Tot de bijzondere kwalificaties, bedoeld in het eerste en tweede lid, behoren niet de behaalde eindexamencijfers.

4. De gegadigde die in aanmerking wenst te komen voor de selectie, bedoeld in het eerste lid, wordt op zijn verzoek door de
Informatie Beheer Groep aan het desbetreffende instellingsbestuur bekendgemaakt, mits hij aan de lotingsprocedure blijft deelnemen.

5. In de ministeriële regeling, bedoeld in artikel 7.57 , vierde lid, worden nadere voorschriften opgenomen voor de toepassing van dit artikel.

Artikel 7.57f. Beperkingen van deelname aan de selectieprocedure

1. Indien krachtens artikel 7.25 nadere vooropleidingseisen zijn gesteld, kan aan de selectieprocedure uitsluitend worden deelgenomen door degene die ten genoegen van de Informatie Beheer Groep het bewijs levert, dat door hem uiterlijk op een in de ministeriële regeling, bedoeld in artikel $7.57 a$, vierde lid, te bepalen tijdstip aan die eisen wordt voldaan.

2. Degene die heeft deelgenomen aan de lotingsprocedure voor een bepaalde opleiding en geen bewijs van toelating heeft verkregen, kan nadien nog ten hoogste twee maal aan de lotingsprocedure voor die opleiding deelnemen.

3. Aan de selectieprocedure kan niet worden deelgenomen door degene die voor een opleiding is ingeschreven of in enig studiejaar was ingeschreven en inschrijving wenst voor dezelfde opleiding aan een andere instelling.

\section{Brief van de Begeleidingscommissie Decentrale Toelating aan colleges van bestuur en het Disciplineoverleg Medische Wetenschappen/Vereniging van Samenwerkende Nederlandse Universiteiten (mei 1999) 7}

- De commissie staat kritisch tegenover aangetroffen criteria die gericht zijn op een (deels) voltooide opleiding in het hoger onderwijs, werkervaring en extra vakken.

- De criteria zijn onvoldoende gericht op de reguliere vwo-abituriënten. 
- Toelatingsbeslissingen moeten worden genomen op basis van subjectieve criteria als inzet, motivatie en specifiek talent.

- Een belangrijke doelstelling is vergroting van de maatschappelijke acceptatie van de selectiebeslissing.

- Faculteiten zouden op een gewenst studentenprofiel kunnen selecteren.

"De begeleidingscommissie constateert echter dat de uitwerking die de universiteiten op dit moment aan de criteria willen geven zich vooral richt op degenen die reeds een al dan niet voltooide opleiding in het hoger onderwijs achter de rug hebben, gegadigden met werkervaring en op een kleine groep scholieren met bij voorkeur twee extra vakken waardoor deze criteria zich maar beperkt richten op de reguliere vwo-abituriënten in het hoger onderwijs." "De begeleidingscommissie merkt voorts op dat een belangrijke doelstelling van het experiment met decentrale toelating is de vergroting van de maatschappelijke acceptatie van de selectiebeslissing. Het gaat daarbij met name om de mogelijkheid voor de reguliere gegadigde om ook via andere dan cijfermatige prestaties toegang te krijgen tot een numerus fixusopleiding. Aldus kan ervaring worden opgedaan met systemen waarbij niet het lot over toelating beslist, maar waarbij toelatingsbeslissingen worden genomen op basis van meer subjectieve criteria als inzet, motivatie en specifiek talent." "Daarnaast geeft zij in overweging aan de selectiecriteria een door de instelling c.q. de opleiding gewenst profiel van de student ten grondslag te leggen."

\section{Rapport van de Begeleidingscommissie Decentrale Toelating (januari 2001) 8}

- Het accent op primaire criteria om het aantal kandidaten te reduceren is te groot.

- Te veel nadruk op extra vakken en bijzondere profieleisen, en onevenredige nadruk op cognitieve prestaties.
- Gepleit wordt voor verkenning van de vrije ruimte, profielwerkstukken, relevante buitenschoolse activiteiten en het te ontwikkelen examendossier.

- Te sterke nadruk op kandidaten met volledige of gedeeltelijke opleiding in het hoger onderwijs.

"Bij haar advisering over de criteria heeft de begeleidingscommissie vooral getoetst op het uitgangspunt dat de gegadigde zoveel mogelijk zijn lot in eigen hand moet kunnen nemen."

"De commissie onderkent de noodzaak in de eerste ronde de grote aantallen aanmeldingen terug te brengen tot een voor de volgende ronde hanteerbaar aantal" ( $p .10)$ en "Er is naar het oordeel van de commissie reeds in dit stadium alle reden vooral kritisch te kijken naar de hantering van de primaire criteria, die naast een inhoudelijke functie ook tot doel lijken te hebben de grote groep aanmelders tot beheersbare aantallen terug te brengen." "De rechtvaardigheid is in het geding als niet iedereen tijdig op de eis van extra vakken heeft kunnen anticiperen en daar waar niet alle scholen voor voortgezet onderwijs de gevraagde vakken aanbieden en kandidaten feitelijk in de onmogelijkheid verkeren aan de gestelde eisen te voldoen. De rechtvaardigheid is ook in het geding waar eisen om bij de eerste gelegenheid te zijn geslaagd geen rekening houden met vertraging door ziekte of andere persoonlijke omstandigheden. Een onevenwichtige nadruk op cognitieve prestaties ontstaat waarbij toelatingscriteria worden gehanteerd die uitgaan van een aanzienlijk hogere studiebelasting dan de reguliere 1600 uren voor de tweede fase voortgezet onderwijs." "De begeleidingscommissie beziet deze ontwikkeling met de nodige zorg. Het vragen van extra vakken en het stellen van eisen die de reguliere studiebelasting ver overschrijden kan leiden tot een categorie scholieren die zich sterk laat leiden door het cognitieve prestatie- 
element, hetgeen ten koste kan gaan van de ruimte voor niet cognitieve prestaties en buitenschoolse activiteiten. Het is de vraag of daarmee het juiste gedrag wordt gestimuleerd. Daarbij dient in aanmerking te worden genomen dat er daarnaast ook al een categorie scholieren zich inspant om een acht of hoger te halen, en er uit dien hoofde al een sterke stimulering van cijfermatige prestaties aanwezig is." "In overweging wordt gegeven in de toekomst andere, alternatieve selectiecriteria te hanteren. De commissie wijst mede na overleg met de Nederlandse Vereniging van Decanen onder meer op verkenning van mogelijkheden binnen de z.g. vrije ruimte, profielwerkstukken, relevante buitenschoolse activiteiten en daarbij het gebruik van het te ontwikkelen examendossier. Een te sterke nadruk op kandidaten die al een gehele of gedeeltelijke opleiding in het hoger onderwijs hebben afgerond gaat ten koste van de kansen voor de reguliere schoolverlater en daarmee lijkt het experiment deels haar doel voorbij te schieten. Dit probleem zal in zwaarte toenemen als de toelatingspercentages hoger worden en naarmate ook andere instellingen meer met dit soort eisen gaan werken."

\section{Brief van de Minister aan de Tweede Kamer (april 2001) ${ }^{9}$}

- Ervoor waken dat er te grote nadruk gelegd wordt op cognitieve prestaties, zodat de reguliere vwo-studielast te ver wordt overschreden; dit staat op gespannen voet met de wetsintentie.

- Het ware beter om via profielwerkstukken, relevante buitenschoolse activiteiten en (bijvoorbeeld) werkervaring inzicht in motivatie en interesses te krijgen.

- Nadruk op een (deels) afgeronde opleiding in het hoger onderwijs gaat ten koste van de kansen van de reguliere schoolverlater en staat op gespannen voet met de wetsintentie.
"Zorgelijk(er) vind ik een ontwikkeling in de richting van een onevenredige nadruk op cognitieve prestaties. Hoge cognitieve prestaties zijn natuurlijk van belang, maar het systeem bevat reeds voldoende prikkels gericht op het behalen van zo hoog mogelijke cijfers, zoals de cijferklassen in de loting (hogere cijfers geven betere kansen) en de mogelijkheid om direct te worden toegelaten bij een acht of hoger. Het ware beter om selectiecriteria te hanteren die aansluiten bij het karakter van de tweede fase voortgezet onderwijs, door mogelijkheden te verkennen om - aan de hand van de profielwerkstukken, relevante buitenschoolse activiteiten en (bijvoorbeeld) werkervaring - meer inzicht te krijgen in de motivatie en interesses van de kandidaten." "In aandachtspunt 2. stelt de commissie dat uit de kwantitatieve gegevens blijkt dat in het wetenschappelijk onderwijs meer dan de helft van de geselecteerde kandidaten een gehele of gedeeltelijke opleiding in het hoger onderwijs heeft afgerond, hetgeen ook naar mijn mening ten koste gaat van de kansen van de reguliere schoolverlater en daarmee - naar de mate waarin meer instellingen met dit soort eisen gaan werken - deels ten koste van de doelstelling van het experiment."

\section{Brief van de Begeleidingscommissie Decentrale Toelating aan de Vereniging van Samenwerkende Nederlandse Universiteiten/ Disciplineoverleg Medische Wetenschappen na overleg met het voorbereidend wetenschappe- lijk onderwijs (mei 2001)10}

- Er ontstaat ongelijkheid doordat de instellingen aanvullende kwalificaties vragen waaraan niet alle gegadigden (en scholen) kunnen voldoen.

- Aanvullende wensen leiden tot te hoge studielast in het voortgezet onderwijs.

- Te weinig ruimte voor schoolverlaters; bepaalde groepen met recht op toelating 
worden bij voorbaat uitgesloten van decentrale selectie.

- Instellingen stellen eisen waarop betrokkenen onvoldoende kunnen anticiperen.

- De diversiteit van criteria is zo groot dat er wildgroei van eisen en criteria ontstaat.

"Uit brieven, gesprekken met schooldecanen en bestuurders uit het voortgezet onderwijs is gebleken dat het vooral om knelpunten gaat als de volgende:

- De instellingen vragen aanvullende kwalificaties waaraan niet alle gegadigden (en scholen) kunnen voldoen, waardoor ongelijkheid optreedt.

- Aanvullende wensen leiden tot aanzienlijke verhoging van de studielast in het voortgezet onderwijs.

- Instellingen willen rapportcijfers (geen examencijfers) laten meewegen bij decentrale selectie.

- Te weinig ruimte voor schoolverlaters en/of bepaalde groepen met recht op toelating worden bij voorbaat uitgesloten van decentrale selectie.

- Instellingen stellen eisen waarop betrokkenen onvoldoende hebben kunnen anticiperen.

- Klachten van decanen, ouders en scholieren dat de diversiteit in toelatingscriteria zo groot is dat er een wildgroei aan verschillende eisen en criteria ontstaat."

\section{Verslag van de bespreking van de Begeleidingscommissie Decentrale Toelating met de medische faculteiten (mei 2001) 11}

- Waak ervoor dat de criteria verkeerd doorwerken in het vwo.

- Voorzichtig met het gebruik van harde eisen en strikt cognitieve criteria.

- Voorselectie op eerdere uitloting is denkbaar.

- Overweeg allochtonen-doelgroep of motivatie voor multiculturele gezondheidszorgsetting.
"De begeleidingscommissie roept de instellingen op meer gevoeligheid te ontwikkelen voor de doorwerking van hun criteria richting voortgezet onderwijs, meer na te denken over het gebruik van niet-cognitieve criteria en voorzichtig te zijn met het gebruik van harde eisen. De wet en het experiment zijn hier niet voor bedoeld. De diversiteit van scholen maakt het gebruik van strikt cognitieve criteria steeds problematischer. "Voorselectie op degenen die eerder zijn uitgeloot is bij voorselectie denkbaar; het is objectief, legt geen beslag op het voortgezet onderwijs." "In het kader van het denken aan specifieke doelgroepen is ook een optie dat gedacht wordt aan bijvoorbeeld de doelgroep allochtonen of gegadigden die bijzonder gemotiveerd zijn voor het werken in een multiculturele setting in de gezondheidszorg."

\section{Samenvatting van aanwijzingen}

De aanwijzingen en opmerkingen die sinds 1997 zijn gemaakt en die bedoeld zijn als richtinggevend voor de ontwikkeling van criteria kunnen worden samengevat in voorstellen die zijn in te delen op een schaal van 'criteria die moeten' tot 'criteria die niet mogen'. In tabel 2 zijn de aanwijzingen samengevat.

\section{Resultaat}

\section{Overzicht van punten die discussie oproepen}

De opmerkingen en aanwijzingen die in de loop van de tijd naar voren zijn gebracht, zijn niet altijd even consistent. Het duidelijkst is dit terug te vinden in het eerste criterium dat in de toelichting bij het wetsvoorstel in 1998 is voorgesteld: examencijfers. Dit criterium wordt in de wetgeving zelf juist uitgesloten. Omdat hierover thans geen discussie bestaat, wordt het hier terzijde gelaten. Er zijn echter talloze andere aanwijzingen die wel tot discussie aanleiding kunnen geven. 
Tabel 2. Indeling van voorstellen ontleend aan aanwijzingen voor de ontwikkeling van criteria.

\section{Criteria die moeten of bedoeld zijn}

- De algemene toelatingseisen voor de opleiding

- Tevens meedoen aan de loting (maximaal $3 \mathrm{x}$ )

- Voorafgaande prestaties (lot in eigen hand)

- Inzet

- Motivatie

- Specifieke talenten

- Relatie met de aansluitende beroepsuitoefening

- Vergroting van de maatschappelijke acceptatie van de selectiebeslissing

\section{Criteria die voorgesteld worden}

- Vrije ruimte in de profielkeuze en profielwerkstukken

- Gerichtheid op de reguliere vwo-abituriënten

- Meer subjectieve criteria ten aanzien van inzet, motivatie en specifiek talent

- Het examendossier

- Relevante buitenschoolse activiteiten

- Werkervaring

- Allochtonen-doelgroep

- Motivatie voor multiculturele gezondheidszorgsetting

- Een facultair studentenprofiel

- Uitgeloot zijn (maximaal 2x)

\section{Criteria die afgeraden worden}

- Beperking deelneming ongemotiveerden

- Voltooide of deels voltooide opleiding in het hoger onderwijs

- Werkervaring

- Extra vwo-vakken

- Criteria met nadruk op primaire criteria om het aantal kandidaten te reduceren

- Criteria met nadruk op bijzondere profieleisen of cognitieve prestaties (harde eisen)

- Criteria waaraan niet alle gegadigden (en scholen) kunnen voldoen of die groepen met recht op toelating bij voorbaat uitsluiten

- Criteria waarop betrokkenen onvoldoende kunnen anticiperen

- Te grote diversiteit van criteria (wildgroei)

- Criteria die verkeerd doorwerken in het voortgezet onderwijs

\section{Criteria die niet mogen}

- Discriminatoire criteria

- Behaalde eindexamencijfers

In de onderstaande opsomming is getracht deze discussiepunten weer te geven met het accent op de tegenstrijdigheden die in de aanwijzingen gelezen kunnen worden.

\section{Cognitieve kenmerken}

1. Cognitieve kenmerken zijn 'harde', meetbare eisen. Het ontraden daarvan levert bewijsproblemen op. Het ver- zoek om helderheid en transparantie, in combinatie met subjectieve eisen en afzien van harde eisen, stelt de faculteit voor bewijsproblemen.

2. Vooralsnog correleren cognitieve kenmerken, zoals vertaald in behaalde eindexamencijfers, het duidelijkst met studieresultaten, zowel in het buitenland als in Nederland. 12213 


\section{Inzet}

3. Het verlangen om de voorgaande prestaties als criterium te hanteren (het lot in eigen hand) staat op gespannen voet met de wens om de studielast in het vwo niet te verzwaren. Indien kenmerken moeten meewegen die de studielast in het voortraject niet vergroten, komt men op kenmerken die losstaan van extra inzet. De wetgever wil echter juist een dergelijke extra inzet beloond zien.

4. Het hanteren van criteria die de vwostudielast niet verhogen, steekt af tegen voorbeelden waaruit blijkt dat leerlingen zich soms extreme inspanning getroosten om een hoog gemiddeld eindexamencijfer te behalen.

\section{Motivatie}

5. Motivatie wordt als belangrijk kenmerk genoemd. In zijn reactie op de wens van de Stichting Lotgenoten dat er een drempel voor ongemotiveerden wordt opgeworpen, geeft de minister echter aan (of 'toe', zo men wil) dat er geen instrumenten zijn waarmee ongemotiveerden kunnen worden geweerd.

6. Motivatie kenmerkt zich ook door de bereidheid door te zetten, ook na uitloting. Expliciet wordt uitloting als selectiecriterium in overweging gegeven. Bij herhaalde uitloting gaat de kandidaat intussen andere dingen doen, bijvoorbeeld een andere opleiding. Alsnog later starten met geneeskunde kan als blijk van grote motivatie worden opgevat.

7. Als uitloting expliciet als mogelijk selectiecriterium wordt genoemd, is het merkwaardig dat kandidaten die driemaal zijn uitgeloot niet meer aan decentrale selectie mogen deelnemen.

\section{Talenten}

8. Bijzondere talenten die geen directe betrekking hebben op cognitieve schoolprestaties, kunnen zeer wel daarmee correleren. Omdat de decentrale selectie zich moet richten op kandidaten met submaximale schoolprestaties, zal men vermoedelijk de bijzondere talenten vaak missen.

\section{Werkervaring}

9. Werkervaring wordt afgeraden én aangeraden als criterium. ${ }^{7} 9$

10. Relevante werkervaring lijkt plausibel als criterium. Het staat echter enigszins op gespannen voet met de wens de selectie te richten op de reguliere schoolverlater. Substantiële werkervaring zal immers vooral na afloop van de schoolperiode zijn opgedaan. Als werkervaring tijdens de schoolperiode wordt opgedaan, kan dit repercussies hebben voor de beschikbare studietijd. Daardoor wordt er wellicht te veel van de scholier gevraagd, hetgeen wordt ontraden.

\section{Discriminatie}

11. Criteria die discriminatoir zijn, mogen niet. Daarmee wordt gedoeld op 'aangeboren' eigenschappen, zoals geslacht, ras, leeftijd, en op eigenschappen of hoedanigheden waarvoor een grondwettelijke keuzevrijheid bestaat (godsdienst, politieke overtuiging, burgerlijke staat). Het gaat daarbij om eigenschappen die in hun algemeenheid niet onderscheidend (mogen) zijn voor het al dan niet kunnen deelnemen aan (hoger) onderwijs zoals de artsopleiding. Leeftijdsdiscriminatie is derhalve uitgesloten. Eén faculteit, die als criterium hanteerde dat de kandidaat niet ouder mag zijn dan dertig jaar, is (terecht) gevraagd dit criterium te schrappen. Niettemin zijn er crite- 
ria denkbaar waarin het element 'leeftijd' indirect een rol speelt, bijvoorbeeld het hebben gevolgd van een vervolgopleiding. Dergelijke criteria zijn juridisch toelaatbaar indien het leeftijdselement daarin niet doorslaggevend is. De sterke nadruk die wordt gelegd op de gerichtheid op schoolverlaters impliceert evenwel dat naar de geest inderdaad jonge kandidaten moeten worden geworven.

12. Decanen in het vwo klagen dat soms kwalificaties worden gevraagd "waaraan niet alle gegadigden kunnen voldoen". Deze vorm van onderscheiding is echter een wezenskenmerk van selectie. Zeker naarmate vwo-scholen meer van elkaar gaan verschillen hetgeen onder de Tweede Fase niet is uit te sluiten - zal dit punt sterker gaan spelen.

\section{Diversiteit en profilering}

13. De faculteiten hebben de opdracht om, zeker in de experimentele fase, uiteenlopende selectiecriteria en -instrumenten te beproeven. De klacht dat de diversiteit van de criteria zo groot is ('wildgroei') is daarmee moeilijk te rijmen.

14. Faculteiten wordt voorgesteld zich te onderscheiden in het studentenprofiel dat zij aantrekken. Hun eindtermen zijn echter bij wet gelijk en pogingen tot profilering in het verleden (zoals gerichtheid op de eerste lijn) zijn op niets uitgelopen.

\section{Primaire selectiecriteria}

15. In het rapport van de Begeleidingscommissie Decentrale Toetsing staan de volgende twee formuleringen: "De commissie onderkent de noodzaak in de eerste ronde de grote aantallen aanmeldingen terug te brengen tot een voor de volgende ronde hanteerbaar aantal" (p. 10) en "Er is naar het oordeel van de commissie reeds in dit stadium alle reden vooral kritisch te kijken naar de hantering van de primaire criteria, die naast een inhoudelijke functie ook tot doel lijken te hebben de grote groep aanmelders tot beheersbare aantallen terug te brengen." (p. 22). ${ }^{8}$

\section{Algemeen}

16. Veel van de discussies rond de te kiezen criteria komen neer op de vraag of zij retrospectief of prospectief valide moeten zijn. Dat betekent een keuze tussen criteria die betrekking hebben op verdienste of geschiktheid, ofwel tussen criteria die als beloning voor het voortraject moeten gelden of moeten anticiperen op toekomstig succes. Hoewel de wetgever het 'lot-in-eigenhand'-principe en voorgaande prestaties als kernpunt beschouwt, wordt ook door de minister aangegeven: “(...) aanvechtbaar lijken in dat verband criteria, die geen relatie hebben met de desbetreffende opleiding of met de daarop aansluitende beroepsuitoefening. "6 Het is duidelijk dat de faculteiten in hun opdracht primair verantwoordelijk zijn voor het afleveren van goede afgestudeerden. Zij hebben een gerechtvaardigd belang in het aantrekken van kandidaten die vlot zullen studeren en goed zullen presteren. $\mathrm{Zij}$ zullen hun niet onaanzienlijke selectie-inspanning dus niet graag richten op het selecteren van kandidaten, uitsluitend om wat zij in het verleden hebben gedaan, maar vooral om wat zij in de toekomst zullen presteren. ${ }^{14}$ Dat belang loopt niet altijd parallel met het verlangen van de maatschappij om scholieren het lot in eigen hand te kunnen laten nemen.

17. De aanleiding voor de discussie over numerus-fixusstudierichtingen vormde 
een briljante scholiere die ondanks een uiterst hoog gemiddeld eindexamencijfer, herhaaldelijk niet inlootte voor de studie geneeskunde. Tegelijk met de invoering van decentrale selectiemogelijkheden kregen kandidaten met een gemiddeld eindexamencijfer van 8 of hoger direct toegang tot de opleidingen. Decentrale selectie moet zich dus richten op vwo-scholieren die in Nederland door het centraal schriftelijk eindexamen toch al een behoorlijk equivalent niveau hebben. ${ }^{15}$ De diversiteit, die tussen scholieren dus al gering is, is aanzienlijk verder ingeperkt door het 'afromen' van de 'beste' scholieren via deze 8+-regeling.

18. De faculteiten zijn door de wetgever vrijgelaten om zelf criteria te formuleren, met enkele beperkingen. Door het grote aantal aanwijzingen dat nadien is verschenen, wordt deze vrijheid niet gestimuleerd.

19. Het selecteren van studenten is slechts van toepassing als er meer kandidaten zijn dan toegelaten kunnen worden. In het Nederlandse hoger onderwijs hebben faculteiten alleen de mogelijkheid studenten te weren, als er een landelijke of een locale numerus fixus is. Tegelijk met de inspanningen om selectieprocedures te ontwikkelen ziet men dat (a) het aantal belangstellende studenten voor de geneeskundeopleiding afneemt en (b) de instroom sterk toeneemt. Wie weet is selectie straks niet alleen niet meer nodig, maar voor de artsopleiding zelfs niet meer toegestaan.

\section{Discussie}

Selectie voor de artsopleiding is een onderwerp dat in Nederland al sinds begin jaren zeventig in discussie is. Pas sinds de recente wetgeving wordt er werkelijk mee geëxperimenteerd. Het is duidelijk dat er met de criteria geworsteld wordt. Zowel door de instanties die het experiment moeten begeleiden en beoordelen, als door de faculteiten. Zo heeft één faculteit vanaf het begin principieel geen selectie ingevoerd en hebben twee faculteiten na aarzeling besloten vooralsnog in 2002 niet mee te doen. Er wordt nog volop gediscussieerd over de vraag of de criteria het voortraject wel op de juiste wijze beïnvloeden. Een antwoord op de vraag over de validiteit in het natraject (Zijn dit ook de betere studenten? Worden dit ook de betere artsen?) laat nog langer op zich wachten. Maar de voortekenen zijn niet op voorhand gunstig indien men examenresultaten buiten beschouwing laat. 13

Het is bekend dat predictoren van academische prestaties niet makkelijk zijn te vinden en, als zij al gevonden worden, in het algemeen moeten worden gezocht in cognitieve prestaties. ${ }^{12} 1617$ Het is het zeer de vraag of de wens van de wetgever om het gedrag van de scholier te beïnvloeden door het hanteren van niet-cognitieve vereisten, verenigbaar zal blijken te zijn met het belang van de faculteiten: goede studenten en afgestudeerden.

\section{Literatuur}

1. Wet van 3 april 1999 tot wijziging van de Wet op het hoger onderwijs en wetenschappelijk onderzoek, houdende aanpassingen in het systeem van selectie voor opleiding waarvoor een toelatingsbeperking is vastgesteld. Staatsblad 1999170.

2. Drenth PJD, Brouwer OG, Buys JWM, Franssen J, Hanekamp LA, Huisjes HJ, Jong U de, Vermeulen CJP, Verweij AMJJ, redactie. Gewogen loting gewogen. Rapport van de Commissie Toelating Numerus Fixus Opleidingen (met bijlagen). Den Haag: SDU Servicecentrum; 1997.

3. Drenth PJD. Selectie in en voor de studie geneeskunde. Bulletin Medisch Onderwijs 1998;17(3)97107.

4. Brief met bijlagen van de secretaris van DMW/VSNU aan de beoogde deelnemers aan het gesprek met de Commissie Sorgdrager op 22 mei 2001. 14 mei 2001. 
5. Ontwerp Regeerakkoord 1998. http://www.nrc.nl/ W2/Nieuws/1998/07/21/Vp/regeerakkoord.html.

6. Toelichting bij de wijziging van de WHW, houdende aanpassingen in het systeem van selectie voor opleidingen waarvoor een toelatingsbeperking is vastgesteld. Kamerstuk 25947 , vergaderjaar 1997/98.

7. Brief van de voorzitter van de Begeleidingscommissie Decentrale Toelating. Fax aan de VSNU, gedateerd 20 mei 1999.

8. Begeleidingscommissie Decentrale Toelating (Commissie Sorgdrager). Rapportage over het experiment met decentrale toelating voor het studiejaar 2000/2001. januari 2001.

9. Brief van de Minister van OCenW aan de voorzitter van de Tweede Kamer. 12 april 2001.

10. Brief van de voorzitter van de Begeleidingscommissie Decentrale Toelating aan de voorzitter van het Disciplineoverleg Medische Wetenschappen. 10 mei 2001.

11. Verslag bespreking Begeleidingscommissie Decentrale Toelating met de medische faculteiten. mei 2001.

12. Salvatori P. Reliability and validity of admissions tools used to select students for the health professions. Advances in Health Sciences Education 2001;6(2)159-75.
13. Cate ThJ ten, Hendrix HL, Fockert Koefoed KJJ de, Rietveld WJ, Studieresultaten van toegelatenen binnen en buiten de loting. (voor publicatie ingezonden).

14. Cate ThJ ten, Hendrix HL. De eerste ervaringen met selectie voor de artsopleiding. Ned Tijdschr Geneeskd 2001;145(28)1364-8.

15. Drenth PJD. In Nederland is selectie onmogelijk Duykerlezing 1995. Wetenschapsbijlage NRCHandelsblad, 30 maart 1995.

16. Gerritsma JGM, Smal JA. Selectie. In: Metz JCM, Scherpbier AJJA, Vleuten CPM van der, redactie. Medisch onderwijs in de praktijk. Assen: Van Gorcum \& comp.; 1995.

17. Jansen P, Stoop B. De relatie tussen eindcijfer VWO, eindcijfer universiteit en beroepssucces. De Psycholoog, april 1998.

De auteurs:

Prof. dr. Th.J. ten Cate, Onderwijsinstituut Universitair Medisch Centrum Utrecht.

Mr. P.J. Klijnhout, Afdeling Juridische Zaken, Universiteit Utrecht.

\section{Correspondentieadres:}

Prof. dr. Th.J. ten Cate, Onderwijsinstituut Universitair Medisch Centrum Utrecht, Postbus 85060, 3584 CG

Utrecht, t.j.tencate@med.uu.nl.

\section{Summary}

Problem: In 1999 Dutch legislation offered medical schools the opportunity of applying qualitative selection as an admissions tool, in addition to the existing national lottery system. The intention was to give high school students more control over their future by inclusion in the admissions criteria of students' special (extracurricular) efforts and achievements as a criterion for eligibility. The intended criteria thus predominantly reflect students' previous activities. The law explicitly excludes the criterion of students' grade point average on the final high school examinations. The criteria developed by medical schools since 1999 do not, in the opinion of some stakeholders, adequately reflect the intentions of the law. This paper analyses intentions and practice.

Method: The analysis addresses the criteria developed by five medical schools for the admissions procedure in 2002/2003. The criteria were judged against six documents reflecting the supposed intentions of the law, i.e. the explanatory notes to the bill, the text of the law as well as subsequent letters from the Minister for Education and the Committee on Decentralised Admission, which oversees the introduction of the selection procedures.

Result: Nineteen points of discussion were identified. Quite a few of the guidelines and recommendations for the development of admissions criteria were found to contain discrepancies. The medical schools that have drawn up criteria since 1999 have so far not managed to reconcile the intentions of the law with the medical schools' best interests.

Conclusion: It is questionable whether the non-cognitive criteria which reflect the intention of the law to stimulate students to take responsibility for their future by rewarding special efforts, are compatible with criteria that predict success in academic and professional life, which are more in line with the interests of the medical schools. (Cate ThJ ten, Klijnhout PJ. Intentions and practice in the application of legislation and guidelines on admission to medical school - an analysis of the criteria. Dutch Journal of Medical Education 2002;21(3): 91-103.) 